\title{
Nietzsche, the 19th Century, and Art
}

\author{
DAVID H. BROWN \\ Northern Virginia Community College
}

I

If we look back upon the 19th century from our vantage point in time, and ask ourselves which of its great thinkers hest comprehended his era, one flgure stands before us: Nietzsche. Enough has been written on the insightful wigdom of this man. Yet if we take "wisdom" to mean "the correct prediction of events," which is what it really means outside of traditional theology and philosophy in the wide-open arena of facts, then we will see that this man hit the mark in contrast to all the progress mongers of his day. Practical wisdom, Aristotle thought, is demonstrated by the one who sires up a situation and successfully foretells what will evolve out of it. Nietziche toid us he was more a prophet than a philosopher.

This essay will elucidate just how successfully Nietzsche's worde prefigured our century and how they must prefigure still some things to come. The secret $\bar{o} \bar{h}$ is revelations came not from a god speaking through him like an ancient oracle, althoigh he was not aware of how accurate he was to be. It is strange that as a prophet, as a "philosopher of the future." to use his phrase, he was almost oblivious to the significance of the major economic and political movements in the $1870^{\prime} \mathrm{s}$ and $1880^{\prime} \mathrm{s}--$ the birth of the German Relch; the challenge to colonial arrogance by Russian presgure in Karakh, Constantinople, and the Balkans; the demise of Erench, English, and Austrian state diplomacy by the dictatorship of wages; the growth of New Yoric City. Particulars like these, tremendous in their historical import, never came in clear focus. His literary training prevented him from feeling deep concern for current events. Nevertheless, an innate talent compensated for this deficiency. Unlike any philosopher of his day or, indeed, down through the ages. Nietzsche was a musician. He sensed naturally his immediate enviromment by its "tempo" or "rhythm." He could feel the pulse beat of this poem or that opera, this man or that woman, this school of thought or that doctrine, to the degree that he came to recognize the tune or melody of the age and compared it to those of former ages. In short. 
Nietzsche detected in the movement of facts the living form they took, saw where this form led before, and then prophesied where it wolld probably end. "reeneology" was the final term he uned for this procedure. It was his way of stepping outside the basic values, assumptions, and feelings of his own century. More specifically, he sensed first what was spiritually close to $h \mathrm{im}$, the artistic forms of the late 19 th contiry. e.g. the music of Wagner, Bizet, and Rrahms; thr poetry of Balldelaire, the Parisian novelists, Tolstoy, Dnstolevsky: the plays of Ibsen. Then he sensed the same "Iife beat." the same Impulses, In llegelian socialism, Darwinian sociology, or the vomantic pessimism nf. Schopenhaver. Einally he compared these impressions, these tumes of lis age, with those he hand of llomnicic Greece. Renaissance Italy, or the Ancien Régime. "To look at the world through the eyes of an aitist." as Nietrsche dercribed this methodology in The Birth of Tragedy, has its limitations and drawback $\bar{k}$, bilt in tive

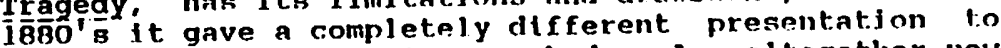
the small audience it reached. An altogether now prophetic philosoplyy of history was produced through an artistic fiair.

The actual beginning of this new approach raine through a personal crisis, one which many other sensitive souls in the 19th century experienced: the incompatiblilty between artiotic life and growing indistrjalization. Name whom you will among the figures of the time--Schiller. Goethe, Balrac, Victor llugo, Wagner, Lisz.t--al1 of them gave utterance to the disparity between their calling and megapolitan existence. But, again. Nietzsche stood apart from them. By a powerful Intultion he perceived in their romanticism, classicism, realism, new realism, historiclsm, art for act's sake--he perceived in all their trends the same underlying beat which characterized alike the banker, the politician, the dreamy idealist, and the educated citizenry. The artists--and I cannot think of one exception--were drawing their source of inspiration from the same elements which formulated the goals for the revolutiondst, the positivist, and the industrialist. N11 of them had one value in common, and we today are still linked to their era because we, In the Western cities, nossess, desplte ourselves, the same fundainental value. We all worghip mall. We are "humanists." whether we are fascists, communists, liberals, republicans, administrators, students, born-again Chrjstians, or just simply "wellwishers." This value is a given of our daily routine. It even determines our dress and what we consider to be tagteful and mannerly. Nietzsche, being by nature an old-fashjoned aristociat, was very sensitive to all this. He was the first to suggest that the artistic "isms" had, as their spiritual counterpart, what others have called "sccialism" and "capitalism," whatever their connotations. This 
new understanding came simultaneously with another Insight: when an artist is a humanitarian, he can only create an art which has no future. There will always be myriad volces shouting down Nietrsche's claim that modern art is dead. But for those who refuse to let themselves be totally fooled, let them consider Nietzsche's argument: modernity is anti-artistic because great art $1 \mathrm{~s}$ anti-humanistic, anti-ethical, antisocial. This is why the priestiy-minded Plato banished the poet from the perfect social order. Gemine art celebrates life, and not the good life; it celebrates existence, and not ordered existence; it exalts tragedy and not justice. Goethe said he could not write tragedy because his soul was "too conciliatory." So tho the whole age. No matter how much poets like Wordsworth and shelley were composing odes to peasantry and nature, and Byron giving his life to Greece, they were at one with the age of utilitarian progress when they assiumed the highest value to be the good of mankind. Even those figures for whom Nietzsche felt an affinity could not escape entirely this world-sentiment--in music Beethoven and Chopin, in poetry Heine; in literature stendahl and Dostolevsky--they represented the glowing sky after sunset.'

But prophetic wisdom takes the present as an interlude. Nietzsche belleved the religion of man first appeared in the literature of Rousseau at the end of the 18th century, when it eclipsed forever the world that he once called die alte Zeit." 2 the world before the French Revolution in which areat art was the manner of living for the upper aristocratic strata in Westernbred nations. He considered his Thus Spake Zarathustra the first real pronouncement of $1 \bar{t}$ end. $\bar{B} u \bar{t}$ just when this pronouncement would cease to be "untimely," when it wolld mirror the spirit of a new era-cone which probably wolld never hear the name of its author-Nietzsche never clearly said. Would it be sjmultaneous with the disappearance of megapolitan existence, and thus outsjide the destiny of Western man? Would it occur somewhere within the gt:ill unlived time of the European humanity? Eor whom would it occur--slavs, Germans, Americans? These questions floated before him. but he did not have the means to answer them. In all cases, Zarathustra spoke of a far-off distant future. More specific pronouncements eluded Nietzische. His misical sense shied before the phenomena of great economic enterprises; before global imperialism; before armored ships, railways, and smoke stacks; before the will-to-power Inside the Ruhr Gebiet. In many ways, his "over-view" was blocked by his nearness to poetry. music, and painting. It worked to the degree it did by his retreat to the south, to the museum of Italy. Nevertheless, it must be remembered that the power of his over-view, as he was aware himself, was to see beyond the individual arts and to take "art" in its 
broader sense to mean "culture." Though he had high hopes for the emergence of a future artist who would have healthier instincts than Wagner, Manet, and Baudelaire,' he had no difficulties in realizing that a truly artistic life in the style of the 17th century was over, that poetry and painting per se were only forms of something more important, that tragic greatness of the distant future did not depend on paint brushes and lyrics.

With this in mind, let us examine first how the political events since Nietzshce's generation have fulfilled his general predictions, and second, why the future world situation has no room for our type of humanity.

\section{I}

Nietzsche's philosophy of art cannot be separated from his understanding of history and politics. They are the same. The past, die alte Zeit, developed both their art and their political form by rules and precepts which unconsciously guarded particular predilections from being brought under serious criticism. The painting schools of Renaissance Italy or the music styles between the 15 th and 18 th centuries in northern and southern Europe were concomitants of small aristocratic states. Likewise the age of social betterment, the age of liberty, fraternity and equality, can witness its spirit both in representative government and in heroes and heroines of novels which invariably portray the middle-class mentajity of cosmopolitan life. The distant future, Nietzsche assured us, will find artisticaliy and politically new boundaries that are inconceivable to us now because it will be a new beginning, not one traversed before, not one evolving out of our time or out of the past. Every society that has experienced exhaustion and loss of direction is swept away by another society with another myth originating somewhere in the depths of nature, demanding a new style of living, believing, working, and perceiving. Granted Nietzsche was considerably vague about the details of this new world of the future, he was certain that the middle-class world of popular rule would be over the moment a founding myth began articulating itself. He wondered whence it would come." He speculated about the results of a mixture between Russian and Germanic peoples, at one time speaking somewhat hopefully about it, at another as the greatest of dangers to the West."

Exact prediction never characterized Nietzsche's genealogical thinking. Only general types, tendencies, and conditions of creativity can be ascertained: Eoremost among the characteristics which he perceived in artists and statesmen during periods of cultural flowering was a kind of "skepticism." To understand 
Nietzsche rightly, we must divorce this term from any scientific meaning. In the end it has nothing to do with an intellectual judgment of decision, especially with the agnostic code of holding one moraliy reprehensible for believing an unverifiable hypothesis. In fact, this 19th century "skepticism" is the exact opposite of what Nietzsche had in mind when he spoke of Caesar, Leonardo, Frederick the Great, Napoleon, Homer, Aristophanes, and Goethe as skeptics." The productive moments of such figures never came by assuming a "standpoint." Scientific, ethical, ideological, and aesthetic judgments are always, as Nietzsche knew, the conclusions of a movement that is itself neither scientific, ethical, ideological, or aesthetic in form. A deed or a judgment which begins with a conclusion can only repeat the conclusion. Though a sense of security be attained thereby, it is achieved only to avoid a deeper indecisiveness. Nietzsche observed this kind of frightened skeptic embodied in the oldest of European states. France of the second half of his century--with its "objectiveness," its scientific spirit, l'art pour 1 'art, and pure voluntary knowledge--took its hskepti$\mathrm{Cism}^{\mathrm{H}}$ to be the only morally correct posture for mankind, whereas it really manifested paralysis of will.' But whatever we may think of Nietzsche's observation of France, the point is clear: conclusive judgment is the freezing of will, while will is the movement directing all judgment. The kind of skepticism prevailing over creative individuals and eras is always prior to all decision, belonging to inclinations, not to reflections. It is given to a few, denied to most, to despise the safety offered by another's work; to have the prejudice of believing nothing true, good, and beautiful save what they alone create; to sacrifice peace, happiness, even Iife to fulfill what appears as a personal dream; to be blind, intolerant, or forgetful of any value or argument that denies this dream.

Nietzsche believed that he alone perceived this hard skepticism of the will in the early Greeks. But he realized that Plato had sensed something of it as well. The exclusion of the artist from the perfect state indicates that this skeptical predisposition is the greatest adversary to "truth." Like Longinus, Nietzsche understood that great art or the great life arises out of a "dangerous" side of nature." Artists-not to speak of the unartistic--as a rule do not sense this quality in themselves, nor do they possess it to a significant degree. Yet the jumps in the history of painting, music, or architecture, just like the political forms of the national state, consistently substantiate that reality goes counter to our primitive wishes for stability, security, peace, permanence, steady progress, and justice. There have always been grounds for the argument that mathematics and the other sciences made their breakthroughs by the spontaneous joyful 
thrust that knocks down the formulated walls of wellestablished truths. Nietzsche, more than any other thinker in his century, demonstrated that all aspects of culture, from science to politics, operate artistically. The first act of the intellect is a creating rather than a recording, which means man is agressive in his sense for the surrounding world, that his primary impulses will always conflict with those impulses beginning from a fearful collsciousness, "reactions" to hostility and misfortune, impulses seeking flight from danger, security, rest, and other-worldly order." When one finds the exceptional individual or people whose character is such that the natural urges to form and shape overcome those to escape or restructure, one has the embodiment of what Nietzsche called "masculine skepticism" or "Eredericanism."10 We read in Beyond Good and Evil that this type discovered in Nietzsche's day a strange outlet in German philologists and historians, "all of them artists of destruction and dissolution," for they were possessed by a "fearlessness of gaze," the sternness of character and courage that Michelet observed not without a shudder: "cet esprit. fataliste, ironique, mephistophelique." '1 Their style of working did not reflect the unquestioned truth of socialism and scientific progress in the manner that. the works of Wagner, Delacroix, Ibsen, or Tolstoy did. As the 19 th century artist came unawares to exist for scientific socialism--for Comte, Darwin, and Spencer--so the statesman came to exist for the interests of the businessman. It was precisely because political policy served economic policy that Nietzsche lost sight and interest in what actually was to shape world history in his century and the next. He did not recognize that a specific form of socialism--Prussian Imperialism, Ecclesiastical Imperialism, or Anglo-Saxon Capitalism--would have to rule international Europe and later the world.

\section{I}

It was easy in Nietzsche's time to be skeptical toward the new utilitarian principles of England, the tenets of any religious faith, the program of a government of communards, or the aesthetic taste in zola's new realism, but no one, save Nietzsche, could be skeptical to the point of doubting the value of critical inguiry. He alone challenged the age by denying that "truth" is the most important value of cultured iife. 12 It is an unessential value to the old artist ard a fatality to the new. And we can see today in retrospect that all theoreticians and pamphleteers between 1770 and 1870, the only period in which principles of knowledge could influence state policy, were in the end ineffective in determining what actual type of social- 
ism was to be, when and where it would originate. All this was finally decided by fighting two world wars.

But the bourgeoisie sustains itself by being criti-

cal. Its work, mission, and structure is critical. The streets, buildings, and industries of any city in Europe or America are faithful images of its mind. Its great talent can be summed up in one word, "organization." Yet this means it is not "creative" in the sense in which Nietzsche used this word. It cannot prolong any great art. This is difficult, nay impossible, for a man of the big city to grasp, gince art surrounds and bewitches him all day long. He is not capable of distinguishing between forming and structuring. This was the case in the last century as it is now. Despite Nietzsche's small contact with the industrial cities, he understood their spirit and purpose. It was the fine artist who said: "O Zarathustra, everything is a lie in me; but that I collapse--this my collapsing is genuine!"ij The artist of the Parisian attic or German spas could still enchant his society, but in doing so he became disenchanted with himself." In short, it is not the pragmatic materialism of a plebian order that corrupted the poet and painter. They themselves lacked the energy to throw off the other-worldly spells of the clergyman, the philosopher, the scholar, and the idealist, and to offer a direction for the rest of society. They were Platonic, or to use Nietzsche's word, they became "priestly" in order to cope with the drive to mechanical organization.

There is a parailel between the disappearance of the great artist of tradition and that of the old-style statesman like Frederick the Great or Metternich and the emergence of men like Bismarck, Napoleon III, and Disraeli, but it is not an exact one. Wagnerian opera demonstrated to Nietzsche that a fine art may carry on a superficial existence by becoming priestly or pragmatic, or a little of both. But a state in Europe could never be priestly at bottom. It never has been. Nietzsche understood that every church or sect that entered the race for survival had done so by imitating the prevalent state forms of the time. He always insisted that it was not in the idea of any clergy to create: it must imitate to endure. ${ }^{35}$ In the end, its aim is to destroy res mundi through a pessimism so deep as to be unfathomable to the bourgeoisie, nobility, or any other order or class of a society. Idealists, philosophers, poets, and scholars have shared from time immemorial this melancholy spirit that yearns for eternal truth above all things." The 19th century, however, may still prove to be their greatest period of political influence. Outside Nietzsche, Dostoievsky appears to be the only one to percieve that the French socialistic theories of Saint-simon, Comte, and Proudhon were so many variations on the older, actual policies of Jesuitical Rome, theories postulating "justice" 
through the collapse of all states, traditions and local habits--all this for the "good of everyone" without regard to class, rank, and nation." Again, in retrospect, it is possible to understand now that Ecclesiastical Socialism was taken up into the anbitions of the Hapsburgs and became a reality in the creation of Latin America. Its final chance for reemergence in France was lost towards the end of the 19 th century when the republican party overcame the last of the royalists. Capitalistic socialism of England and America, on the other hand, became a reality by respecting in theory "Liberty, Equality, Brotherhood," but disregarding the motto in practice. Whenever a political dream is the product of the critical intellect, it is "priestly," no matter how atheistic or anti-clerical it appears, and therefore, it is always impractical and nihilistic."

The point is this: the new reign of the middle class destroyed by means of finance capital and industrialization the fine arts and politic of unconscious tradition, and there appeared in their place a pseudoart of pessimistic, irreligious priesterdom, which is the death of art, and a politic that uses the same pessimism for the ends of national or private economy. which is flat materialism. This was the framework of Nietzsche's world, and the reason he estranged himself from it. He understood what no one else understood, namely the "third estate" can never experience greatness--n. . . great misfortune, great ugliness, great failure. . " 19 --greatness in any respect, despite the putting on of airs, the imitating of aristocratic bearing. If the popular mentality could not see the obvious superiority of Handel. Bach, and Mozart over Wagner and Brahms, it was going to misinterpret the philosophy of self-surpassing.

Nevertheless, Nietzsche overcame cynicism and disgust for his age in his long masterpiece. Not all was hopeless. 1789 and the growth of the corporate world of London, Hamburg, and Paris were the ground from which the "anachronism" of the century sprang. 20 Napoleon I had come to power on the principles of modern economy and representative governinent, and he fell by the same. The Corsican was the first symbol of a phenomenon that has repeated itself, in less and less Romantic color, in more and more circumspect ways. through two centuries of European and American history. How often has "Republicanism" fostered "Imperialism," then opposed it? Even Nietzsche, in voluntary exile and with no concern for contemporary politics, must have been at least dimly aware of the new situation. The conflict between the interests of economy and interests of politics did not suddenly begin in recent decades." The 19th century observed the West European nations converting the old monarchial and aristocratic state of previous centuries into an organ operating es- 
sentially in behalf of private income, but as soon as any leading government carried out policies toward other states, it would inevitably reveal intentions contrary to "free enterprise," intentions that, when fulfilled, would make all economic problems secondary to the existence of an imperial state. In short, the structure of modern economy begs the existence of imperial politics, but it continually dismantles the imperial state for maximization of profit. The battle between economics and politics, business and government, capitalistic socialism and imperialistic socialism, has already been fought between nations and within nations, Western and non-Western. It should be evident to us in the late 20th century that the defeat of Germany in the two world wars was the defeat of military or Prussian-style socialism, and the victory of the Western Allies meant the continuation of AngloSaxon international-capitalism.

\section{IV}

It is interesting that Nietzsche predicted the first of the world wars.22 Yet his mind could not dwell too long on the mounting crisis. He continued to look upon things from another perspective, another age, either through the past or future. Rather than states, he concentrated on individuals, not Bismarck or Wilhelm I but on individuals as types. It still seems strange to us to read that it was not something like the "Anglicising" of the continent that threatened Europe 's future, but the priest; not the surge of Communism in Paris, but Christian pity. We still have not grasped the implications of the genealogical argument. When Nietzsche looked at Wagner's audience in Bayreuth, he saw neither the past nor the future of a lasting mankind, only the bad taste of modernity, of an upper middle class organizing financial security for individual "egos," for small-minded, small-ranging, separate atoms, not for a type, for a universal form like the Prussian Adel, French Noblisse, or Jesuit society of priests and conquistadors. The new materialism showed one positive sign to Nietzsche, namely the growth of atheism, or the possible weakening of the priestly man's stranglehold over the 19 th century. But the middle class is, in its way, like a simple peasantry, in that it is drawn into and shaped by two opposing principles. Despite newspapers and all the noise of technology, history is a struggle between the other-worldly "nay" and this worldly "yea." Even though the best representatives of the two, the nobleman and the priest of feudal society, no longer figure in contemporary events, the conflict itself takes on a different appearance, thereby deceiving forever the eye of most historians. The soldier, businessman, and the worker, just like the barbaric woodsman, peasant, and nomad, 
are the "human, all-to-human" matter for the battle between earth and heaven.

Nietzsche's philosophy of history is yet to be appreciated because the power of the priest is always incorrectly gauged, particularly in the 19th and 20th centuries, and because the counter-force, "the superman," is completely misunderstood by a middle-class vision of things.

Once and for all, the superman is an Urphänomen, a primal image to be sensed only through a comparison of classes, professions, orders, nationalities, epochs, even of its antithetical form, the priest. But it appears that Nietzsche intuited this primal type most often and most clearly in the artist. No artist has ever been superhuman, yet fine art at its best has the superhuman in $i t$, and Nietzsche expressed what it was when he said: "In art the end does not justify the means, but holy means can justify the end." 23 Whereas the pure statesman, politician, soldier, merchant, and technician orient their work around a successful future, and whereas the priest, saint, philosopher, and theoretician contemplate other possible worlds, truths, or eternal laws--the artist encounters the world as it is in the present. His task is not "world-betterment" or revelation of a greater reality beyond sense experience. A drama by Aeschylus or a painting by Van Dyck or Raphael (but not Delacroix) came not from a need to make an important statement, to convey knowledge, or to comminicate. " In fact, fine art emanates out of impulses seeking to overcome pragmatic or priestly values. 23 The artist of "die alte Zeit" was neither a man of action nor a thinker. Insofar as every great art work is a "thanksgiving" and a "benediction," as Nietzsche said, it served an utilitarian function, that of stimulating the zest for life. ${ }^{2 s}$ This end is attainable only by "holy means," that is, by the present world, just as it is, apart from a plan to reformulate it or to escape from it. Reverence and awe for the sensuous moment is a feeling that neither the pure man of fact nor of theory can comprehend.

But to intuit the superman type in the activity of art is to sense "art" in its broadest meaning, to take it to be almost synonymous with "creativity" or "culture." When any work, including that of the churcliman, becomes a celebration, it loses the spirit of "worlddenunciation" or of "world-improvement," both being at bottom the same. This means that culture, as historical development, is anti-pragmatic and anti-clerical. Though we know Nietzsche had personal limitations concerning natural philosophy and mathematics, he realized they, like the European national states, were all works of art, works of love. Albert Camus observed that totalitarian governments react negatively towards art for the same reason plato did: art, at its best, denies that social order is the highest value; culture 
in general undermines order as the vital element of life.27 The very existence of grand art is a denial of any totalitarian order or any democratic order. All forms of modern government are opposed to the tragic sense for things. How wrong sartre was when he said that creativity depended upon democratic freedom!" Creativity is not "humanistic," but "superhumanistic," which means it $i s$ beyond good and evil, beyond all ideology, all scientific organization of life, all programing.

"Art," for a Nietzschean reader, is an affirmation of the "consequenceless" nature of things. When one celebrates the moment, the unconscious side of existence plays with present impressions, and makes of the art an expression not of individual consciousness, but of unconscious nature in the individual. How ridiculous for poets to equate Beauty and Truth! The former is always sensuous and excites the cosmic will; the latter is intellectual, and as Nietzsche put it, "The Will to Truth' is the will to impotence." 20

\section{V}

No philosophy was ever as untimely as Nietzsche's. Who in 1890 was going to find "art" and the love of beauty as something altogether different than the taste of effeminate, dreamy natures? Who today will? Who can perceive culture as "Frederician skepticism"? But again, as Nietzsche argued, the downfall of Western man is not a problem of his perception or understanding, but a defect in his character, in his being--in his being too "responsive," too much driven to seize the image projected by the warning signs of the nervous system." Nobility presupposes a disposition ruled primarily by the primitive demands of "blood." 31 Zarathustra says, "Where is beauty? Where I must will with my whole Will; where I will love and perish, that an image may not remain merely an image." 12 The antecedents of cosmopolitanism cannot allow a present-day man to realize these words of Zarathustra, this noble disposition. He has forfeited to the needs of stability and security, to the defense of life, the will to love the "innocence of Becoming," bellum omnis contra omnem, beyond good and evil. To most, whatever era and rank, fate is cruel, but the modern temperament cannot ennoble its suffering. It is compelled to denounce in practice and theory, by religion and science, suffering as evil. Technology, the city, the church--are all efforts to avoid fate. The basic assumption of present global civilization is that consummate strength must work to freeze the natural transformation of all things, to halt, even to kill fate 1 tself by organization, whereas Nietzsche demonstrated this assumption as the unequivocal sign of fear, of advancing senility, and a general weakening of our nature, of our will to 
power. A sound constitution does not behave too "defensively" or "responsively," or what amounts to the same in our age, as though existence were evil and unjust. It is not impelled to make thinking, living, and history into a program. Achaean Greece was ever for Nietzsche the counter image of modernity. With the energy of wild youth, the Greek heroines and heroes, legendary saints and prophets, blindly reached out to meet fate, but without the cynicism and spirit of revenge sometimes associated with youth. On every occasion, they met events without care about tomorrow, about "life for the sake of life," though they themselves were, without knowledge and truth, the real future. It manifested that beauty which lived and died for an image created by the body, not by the imagination of an intellect, not by the electricity at nerve endings. A young will can overcome fear, which is waking-consciousness, and direct the nervous system to realize myth, regardless of conseguence. This mode of living, what Heidegger once called "raging art," is courage. Zarathustra says to his guests at the cave. "For Fear--is an exception with us. Courage, however, and adventure, and delight in the uncertain, in the unattempted--courage seemeth to me the entire primitive history of man."3 Beauty is the "Amor Fati." Therefore, it is not the Truth or the Good: it is not what we can consciously make of them, but what our living unconscious nature makes of us. This is why Nietzsche found tragedy to be more profound than philosophy. The courage to throw 1 ife away from an overabundance of strength, for an image to become a reality, is botl, the characteristic of any form of greatness and the epitomy of the "consequenceless" flow of reality. The sublime sense of life sounded hopelessly ridiculous to Nietzsche's contemporaries. Hence, modern literature and clothes, even the manner in which symphonies were performed, filled Nietzsche with contempt.

Although considerably blurry. Nietzsche's untimely predictions are much more realistic than one shall ever meet in the works of Comte, Fourier, and Marx. We can count on the disappearance of our type of man, and with him the middle-class perspective which has governed the West since the Enlightenment. But it will not, however. be replaced with a higher stage of "culture," notwithstanding all the fictions imagined over the last two centuries. The end of the 20th century is like the end of the 19th in that the same fire is consuming us as it was Nietzsche's contemporaries; the same fire is segregating us from the past and the future. In fact, the meaning and the task of our civilization are both the breaking away from the work and traditions of the past and the preventing of any future idea from flowering. Of course, we do not see it the way Nietzsche did. We belleve our whole effort is trying to save mankind from the evils of the past for the good of the future. 
This has been the mandate of every political party since the Erench Revolution. We call it "progress" or "development." But nothing is more absurd as to think the present interlude is a step forward, in actuality or in intention. What good humanitarians are saving is nothing but an image of themselves which they call "mankind." "Humanism," "scientific progress," "economic development"--these catchy words imply that as long as we understand the tribulations of man, love culture and history, admire what "man" has achieved in the struggle for betterment, as long as we keep up the same fight, we cannot expect better of ourselves. The contrary is the case. The worship of man is nihilistic. Dostoievsky realized that our brand of humanism will finally exhaust the West through the democratic tendency of trying to keep satisfied the lower and middle classes." other nations outside the circuit of our society do not have to contend with this "manreligion." They are basically content.

It is hard to imagine a world devoid of middleclass cosmopolitanism. But we can overcome the difficulty if we make the same effort Nietzsche did; if we perceive what he meant by the "superman" type, we will have some idea of the distant future. In the final part of Zarathustra, the prophet teaches his guests. the higher men--the kings, the pope, the magician, the soothsayer, and the rest--without word, with personal example and demonstration, to laugh while dancing. What does this scene mean? The future man will be like the man of "die alte Zeit" in that he will not perceive by ratiocination. He will not abstract reality and take the abstraction as reality. Wars, societies, and events will be shaped in some way other than by meter sticks and "bodies in perpetual motion." Our age--the 19 th, the 20th, and perhaps the $218 t$ centuries--could possibly be the most artificial age ever to have been. Yet, when the destiny of mind over matter, reason over instinct, has fulfilled itself, another destiny will replace our mode of existence, and whatever the locality or blood stream from which it will issue, it will be more lasting, more basic, one that will prove to be more of the norm in the flow of the entire history of man, not just of the West. The cosmopolitan type is an exception, not the rule--and the future, therefore, will be in this respect a return to the primitive Urphänomen that has prevailed in the great stretches of world history. Laughter and dance together are moments when the body overcomes the brain, the beat of blood the detached perception of things, moments that are the Urphänomen, the superman type. When Zarathustra performed his wild, ecstatic dance, he evoked in those present a joy of the moment, the world as it is here and now, at high noon and midnight, untouched by the anxiety of learned men. The future man will not experience a higher stage of artistic culture by either 
present or past measurements, but he will be, whether barbaric or highly civilized, more "artistic" in the deeper sense Nietzsche took the word. A man whose soul is not defeated by $\mathrm{misfortune}$ is one who realizes in the health of his body the joy that is deeper than all woe. "s Art is the only genuine metaphysical activity. Nietzsche declared to Wagner, 36 and the only genuine art is a joyful activity of the body. Dancing, composing, painting, or thinking--in contrast to the dance, the poem, the painting as topic of analysis, or the thought of a system--is a "becoming," and as Goethe said, "unaussprechlich," unspeakable, comprehended not by causal formulation. But all creativity, human and cosmic, in war and peace, is a becoming, and is unspeakable, comprehended by no word, only by the deep joy that is no monkish thing-in-itself, no schopenhaurian will. Laughter, said Zarathustra, kills every argument: it is the real living will dispeliing the phantom called "truth." The future, no doubt, will still hold its religious observance," for the same reason Zarathustra's guests, after their nightly revelry, prepared to master, like every dumb plant and creeping animal, their own worlds. They must prepare, not out of fear for survival, out of egoism per se, but out of a love, a will, that will always surpass the stage of fearful existence. The superman's mastery of the conditions of his own existence, therefore, will not be another form of imperialism, but the Homeric ethic bearing victory or defeat as opportunity of unconscious nature to create its own order.

Indeed, all this talk about the "future man" sounds foolish and childish. To us, to our age, it has to sound foolish and childish, just as it sounded to the Egyptian priest that Plato admired: "O Solon, Solon, you Hellenes are never anything but children, and there is not an old man among you." " But it sounds so because we, like the Egyptian priest, cannot love this world; we have no longer any star in front of us. A purely humanistic, cold, practical intelligence can only reflect the dreams of other ages and people. To present cultural leaders, Zarathustra says: "All periods prate against one another in your spirits; and the dreams and pratings of all periods were even realer than your awakeness!" " For all its innovation, our age is elderly and unable to have its own dream: "Unfruitful are ye: therefore do ye lack belief. But he who had to create, had always his presaging dreams and astral premonitions .... "Wo Nevertheless, insofar as each of us experiences in our daily routine the joy of a moment, purely and clearly, without cynicism, do we foreteli unawares something of a future type. Though we, like the higher men at Zarathustra's cave. are not the future, the currents of the future are in us, and we are, despite ourselves, bridges to another age and a world which will never know the pragmatic 
nature possessing us. What will survive us--hard as it is to believe--is nothing of our serious intentions, nothing of our man-religion, our democratic socialism, our liberalism, our capitalism, nor the growing disillusionment and world-wide nihilistic attitude toward these serious intentions, which were also born at the end of the 18th century. The moments in which we forget our late idealigm or "get-tough" realism, we, even we, become "artistic" in Nietzsche's sense and experience something also of "die alte Zelt" before the dawn of industrialization. When we laugh from dancing, the rhythm of nature wills anew an untimely disposition. Gaiety, which is the eternity of nature for Nietzsche, will continually break the crust of Western utilitarianism, and will filter down to new generations, gathering momentum with the passage of time; while the serious business of world-organization will become progressively felt as impossible, and the greatness we sense therein will have disappeared with it. This future will take a form seen before: a new era blossoms when a generation is reached that approaches everything--war, building, thinking--by playing. The blindness and naivety in the worlds of the early Greeks or Gothic knight are evident in their surviving remnants of our museums. New creators are children and have no choice but to play out their dreams. Therefore the children of the future, the supermen, will inherit nothing of our ponderous work or our cynicism, but like all other children of history, on the "wheel of recurrence," they will be vibrant in the neceselties of survival because they are made by nature to be forgetful of danger, to be daring and foolish, to be more artful than dutiful, to look for unexpected accidents everywhere, to be unconsciously grateful for things just as they are, and therefore to worship the earth by instinct. The children of tomorrow can only inherit what may happen to add to the "Gaiety transfiguring all that dread." 4 Being controlled by nature, the child is possessed by the wisdom of instincts, which easily disregards the reasoning, yet accepts the rhythm in the nine steps of its forefathers so as to be able to take the tenth with the same rhythm. Thus the Nietzschean ethic to each higher man: "Thou must yet become a child, and be without shame." "2 But Zarathustra could not, even though "in the true man there is a child hidden: it wanteth to play."'s Too much has been destroyed in the age of progress; the music, the dynastic state can never be restored, nor the activity that created them. This is why Nietzsche stumbled when it came to trying to figure out how one could set up again the conditions for the future man. It would be another program, hence futile. It would be the same sort of vanity Nietzsche noticed in the typical artist: the enforcement and hording of a little life by simpleminded calculation." As he said, Achilles would not 
have been a Homer."s The pope, the kings, the soothsayer, and all others seeking solace at Zarathustra's cave must find it in the "future return," which is an "eternal return." The spinning of eternity is a joyful will: a joyful will alone survives time and death.

\section{NOTES}

'Friederich Nietzsche, Werke in Drei Banden (Munich: Carl Hanser Verlag, 1980), I, $\overline{582}$. Hereafter Nietzsche. Translations are from The Complete Works of Eriederich Nietzsche (New York: Russeli and Russeli. 1964).

'Ibid., II, 711. "Die 'gute alte' Zeit ist dahin, in Mozart hat sie sich ausgesungen . . .

'Ibid., II. 935.

Ibid., I I I, 432. Cf. I I, 1016.

Ibid. , II, 672 .

Ibid., III, 518 .

'Ibid. , II, 671 .

Ibid., 166.

Ibid., I, 1036 and 1130 .

10 Ibid., II, 673 .

${ }^{11}$ Ibid. , 674 .

12 Ibid. , 567 and 891.

"Ibid., 495.

"Ibid. . 742-4.

is Ibid., 387. Cf. also 1198, 1216, 1235, and III, 641 and 664 .

16 Ibid.., II, 936.

${ }^{17}$ Fyodor Michailovitch Dostoievsky. The Diary of a Writer (New York: Charles Scribner's Sons, 1949), III, 719-46. Hereafter Dostoievsky. Cf. also Nietzsche, II, $612 \mathrm{f}$. 
${ }^{10} \mathrm{Cf}$. Nietzsche II, 1167 and III, 549 and $677 \mathrm{f}$.

"Ibid., II, 503 .

20 Ibid. 796.

21 Ibid., II, 1148; III, 623, 809, 820 and 1324.

22 "Within fifty years these Babel governments will clash in a gigantic war for the markets of the world."

2 Ibid.. I, 789.

"Ibid, III, 832 .

${ }^{28}$ Ibid. , I, 614, 940, and III, 271.

2I Ibid., II, 1004; III, 692 and 753 .

2'Albert Camus, The Rebel (New York: Alfred Knopf, 1956), 253-72.

2Jean-Paul Sartre, "Why Write?" In Critical Theory Since Plato, ed. H. Adams (New York: Harcourt, Brace, Jovanovich, 1971), p. 1068.

2'Nietzsche, III, 549.

"Ibid., I I, 1133.

"Cf. Ibid., II, 350.

32 Ibid. , 379.

3 Ibid. , 538.

"Dostoievsky, I, 296.

${ }^{35}$ Nietzsche, II 556.

"Ibid. , I, 20.

"The necessity for the future man to hold religious observance is the meaning of the "Ass-Festival" in the last part of Zarathustra.

"Plato, Timaeus, 22B.

"Nietzsche, II, 376 .

"Ibid.

"W. B. Yeats, "Lapis Lazuli."

"'Nietzsche, II, 401. 
"Ibid., 329.

"Ibid.. I, 723.

"s Ibid. , 571. 